\title{
IMPLEMENTASI MODEL POE2WE DALAM LKS MATERI ELASTISITAS BAHAN DENGAN MENGGUNAKAN MICROSOFT TEAMS UNTUK MENINGKATKAN KUALITAS PEMBELAJARAN FISIKA
}

\author{
Rhifa Diana ${ }^{*}$, Nana $^{2}$ \\ ${ }^{1}$ Mahasiswa Pendidikan Fisika, Universitas Siliwangi \\ ${ }^{2}$ Dosen Pendidikan Fisika, Universitas Siliwangi \\ *email korespondensi : rhifadiana15@gmail.com
}

\begin{abstract}
This research aims to implement the POE2WE model in the material LKS material elasticity using Microsoft Teams as a form of utilization of digital technology. In this study the topics covered are stress, strain, modulus of elasticity, and Hooke's Law. This study uses a qualitative approach in the form of descriptive theoretical data with literature study techniques. By using these models and methods the researcher can elucidate the material concepts of material elasticity in worksheets more easily to students. The results of this study indicate that interactions between educators and students are easier and more active. Educators become easier in delivering material to students with the facilities provided from Microsoft Teams. Likewise with students can more freely interact with educators also with their friends because it is not limited in space and time.
\end{abstract}

Keywords: POE2WE Model, LKS, Material Elasticity, Microsoft Teams

\begin{abstract}
Abstrak: Penelitian ini bertujuan untuk mengimplementasikan model POE2WE dalam LKS materi elastisitas bahan dengan menggunakan Microsoft Teams sebagai bentuk pemanfaatan teknologi digital. Pada penelitian ini topic yang dibahas yakni tegangan, regangan, modulus elastisitas, dan Hukum Hooke. Penelitian ini menggunakan pendekatan kualitatif berupa data teoretis deskriptif dengan teknik studi pustaka. Dengan menggunakan model dan metode ini peneliti dapat menguraikan konsep-konsep materi elastisitas bahan dalam LKS dengan ebih mudah kepada peserta didik. Hasil dari penelitian ini menunjukan bahwa interaksi antara pendidik dan peserta didik lebih mudah dan lebih aktif. Pendidik menjadi lebih mudah dalam menyampaikan materi kepada peserta didik dengan adanya fasilitas yang diberikan dari Microsoft Teams. Begitu juga dengan peserta didik dapat lebih leluasa berinteraksi dengan pendidik juga dengan teman-temannya karena tidak terbatas dalam ruang dan waktu.
\end{abstract}

Kata kunci: Model POE2WE, LKS, Elastisitas Bahan, Microsoft Teams

\section{Pendahuluan}

IPA merupakan cabang pengetahuan yang berawal dari fenomena alam (makmur sirait, dan putrid adilah noer, 2013) IPA didefinisikan sebagai sekumpulan pengetahuan tentang objek dan fenomena alam yang diperoleh dari hasil pemikiran dan penyelidikan ilmuan yang dilakukan dengan keterampilan bereksperimen dengan menggunakan metode ilmiah (Sukoharjo, 2012). Fisika merupakan salah satu cabang dari IPA, karakteristik pembelajaran fisika menurut Wahyu Arini dan Fikri Juliadi (dalam Sari, dkk.2018) adalah pembelajaran yang membutuhkan daya nalar dan analisis sehingga perlu diadakan peningkatan penguasaan konsep melalui pembelajaran bermakna. Oleh karena itu diperlukan suatu alternative yang bias digunakan untuk meningkatkan proses pembelajaran fisika.

Sebagai upaya untuk meningkatkan motivasi peserta didik dalam pembelajaran fisika, pemanfaatan teknologi digital haruslah digunakan untuk menarik perhatian peserta didik dalam pembelajaran. Teknologi digital tersebut disesuaikan dengan kondisi dan karakteristik peserta didik. Salah satu yang dapat digunakan dalam menerapkan pembelajaran berbasis teknologi digital adalah dengan menggunakan Micsrosoft Teams. Microsoft Teams adalah salah satu jenis situs pencarian google yang bisa digunakan untuk berinterkasi dengan orang lain, salah satunya 
yakni dalam bidang pendidikan. Dalam bidang pendidikan, pendidik dapat lebih mudah menyampaikan materi secara tidak langsung (online). Begitu juga dengan peserta didik, mereka dapat lebih mudah untuk berinteraksi dengan pendidik dan peserta didik lainnya dengan tidak terbatas dalam ruang dan waktu.

Menurut Nana, dkk (2014) Model POE2WE memiliki enam langkah utama dalam pembelajaran yaitu 1) Prediction (Prediksi) atau membuat dugaan, merupakan suatu proses membuat dugaan terhadap suatu permasalahan yang diberikan guru. Dalam membuat dugaan siswa sudah memikirkan alasan mengapa ia membuat dugaan seperti itu. Dalam proses ini siswa diberi kebebasan seluas-luasnya menyusun dugaan dengan alasannya, sebaiknya guru tidak membatasi pemikiran siswa sehingga banyak gagasan dan konsep yang muncul dari pikiran siswa. Pada proses prediksi ini guru juga dapat mengerti miskonsepsi yang banyak terjadi pada siswa. Hal ini penting bagi guru dalam membantu siswa untuk membangun konsep yang benar. 2) Observation (Observasi) yaitu melakukan penyelidikan, pengamatan apa yang terjadi. Dengan kata lain siswa diajak untuk melakukan percobaan, untuk menguji kebenaran prediksi yang mereka sampaikan. Pada tahap ini siswa melakukan penyelidikan/eksperimen, untuk menguji prediksi yang mereka ungkapkan. Siswa mengamati apa yang terjadi, yang terpenting dalam langkah iniadalah konfirmasi atas prediksi mereka. (3) Elaboration (elaborasi) yaitu mengaitkan materi yang dipelajari peserta siswa dengan kehidupan sehari-hari, (4) Explanation (eksplanasi) yaitu pemberian penjelasan terutama tentang kesesuaian antara dugaan dengan hasil eksperimen dari tahap observasi. Apabila hasil prediksi tersebut sesuai dengan hasil observasi dan setelah mereka memperoleh penjelasan tentang kebenaran prediksinya, maka siswa semakin yakin akan konsepnya. Akan tetapi jika dugaan tidak tepat maka siswa dapat mencari penjelasan tentang ketidaktepatan prediksinya. Siswa akan mengalami perubahan konsep dari konsep yang tidak benar menjadi benar. Disini siswa dapat belajar dari kesalahan dan biasanya belajar dari kesalahan tidak akan mudah di lupakan. (5) Write (menulis), pada tahap ini siswa menulis kesimpulan dengan bahasanya sendiri, (6) Evaluation (Evaluasi), pada tahap ini siswa diuji dengan berbagai pertanyaan mengenai materi yang telah dibahas dan telah dipelajari. Penelitian ini dikembangkan dengan memadukan Antara model POE2WE dengan Microsoft Teams. Dengan dipadukannya model POE2WE dengan Microsoft Teams dalam materi fisika elastisitas bahan, maka diharapkan akan meningkatkan hasil pembelajaran peserta didik dan lebih mempermudah pendidik dan peserta didik dalam melakukan proses pembelajaran selain dengan tatap muka (face to face).

\section{Metode Penelitian}

Penelitian ini menggunakan pendekatan kualitatif berupa data teoretis deskriptif dengan teknik studi pustaka. Artinya penulis mengambil data melalui literatur yang sesuai dengan 
penelitian yang dilakukan, Penulis juga menguraikan permasalahan dengan mendeskripsikan secara jelas dan objektif.

\section{Hasil dan Pembahasan}

Penerapan model POE2WE ini dikhususkan pada materi Fisika yakni elastisitas bahan. Penelitian ini difasilitasi oleh salah satu situs pencarian google yakni Microsoft Teams. Hal ini bertujuan untuk menunjang proses pembelajaran yang lebih memudahkan pendidik dan peserta didik dalam berinteraksi dengan tidak terbatas dalam ruang maupun waktu. Dan dengan adanya fasilitas di dalam Microsoft Teams dapat lebih mudah dalam pemanfaatan teknologi berbasis digital dengan memadukan model pembelajaran POE2WE pada LKS materi elastisitas bahan.

Menurut Belawati (Dwi Arianti :2015), Lembar Kerja Siswa (LKS) adalah suatu bahan ajar cetak berupa lembar-lembar kertas yang berisi materi, ringkasan, dan petunjuk-petunjuk pelaksanaan tugas pembelajaran yang harus dikerjakan oleh peserta didik, yang mengacu pada kompetensi dasar yang harus dicapai.

Menurut Pane, Aprida (2017) Belajar dan pembelajaran adalah dua hal yang saling berhubungan erat dan tidak dapat dipisahkan dalam kegiatan edukatif. Belajar dan pembelajaran dikatakan sebuah bentuk edukasi yang menjadikan adanya suatu interaksi antara guru dengan siswa. Kegiatan belajar mengajar yang dilakukan dalam hal ini diarahkan untuk mencapai tujuan tertentu yang telah dirumuskan sebelum pengajaran dilakukan.

Menurut Undang-undang Republik Indonesia Nomor 20 tahun 2003 tantang Sistem Pendidikan Nasional, bahwa pembelajaran adalah proses interaksi pendidik dengan peserta didik dan sumber belajar yang berlangsung dalam suatu lingkungan belajar. Secara Nasional, pembelajaran dipandang sebagai suatu proses interaksi yang melibatkan komponen-komponen utama, yaitu peserta didik, pendidik, dan sumber belajar yang berlangsung dalam suatu lingkungan belajar, maka yang dikatakan dengan proses pembelajaran adalah suatu sistem yang melibatkan satu kesatuan komponen yang saling berkaitan dan saling berinteraksi untuk mencapai suatu hasil yang diharapkan secara optimal sesuai dengan tujuan yang telah ditetapkan.

Model pembelajaran Prediction, Observation, Explanation, Elaboration, Write dan Evaluation (POE2WE) dikembangkan dari model pembelajaran POEW dan model pembelajaran Fisika dengan Pendekatan Konstruktivistik. Pengembangan ini dilakukan untuk sebagai penyempurnaan kedua model sebelumnya. Model POE2WE merupakan model pembelajaran yang dikembangkan untuk mengetahui pemahaman peserta didik mengenai suatu konsep dengan pendekatan konstruktivistik. Model ini membangun pengetahuan dengan urutan proses yaitu meramalkan atau memprediksi solusi dari permasalahan, melakukan eksperimen untuk membuktikan prediksi, kemudian menjelaskan hasil eksperimen yang diperoleh secara 
lisan maupun tertulis, membuat contoh penerapan dalam kehidupan sehari-hari, menuliskan hasil diskusi dan memuat evaluasi tentang pemahaman peserta didik baik secara lisan maupun tertulis (Nana et al., 2014; 2016).

Penggabungan tahapan-tahapan pembelajaran model POEW dan model pembelajaran Fisika dengan Pendekatan Konstruktivistik maka dapat di susun langkah-langkah pembelajaran model POE2WE secara terinci sebagai berikut (Nana dan Surahman, 2019; 2020):

\section{a. Prediction}

Tahap prediction yaitu peserta didik membuat prediksi atau dugaan awal terhadap suatu permasalahan. Permasalahan yang ditemukan berasal dari pertanyaan dan gambar tentang materi yang disampaikan oleh guru yang ada di Lembar Kerja peserta didik (LKS)/buku peserta didik sebelum peserta didik membuat prediksi. Pembuatan prediksi jawaban tahap Prediction pada model POEW identik dengan fase Engagement pada pendekatan konstruktivistik. Guru mengajukan pertanyaan yang dapat mendorong peserta didik untuk dapat membuat prediksi atau jawaban sementara dari suatu permasalahan.

\section{b. Observation}

Tahap Observation yaitu untuk membuktikan prediksi yang telah di buat oleh peserta didik. Peserta didik diajak melakukan eksperimen berkaitan dengan masalah atau persoalan yang di temukan. Selanjutnya peserta didik mengamati apa yang terjadi, kemudian peserta didik menguji kebenaran dari dugaan sementara yang telah dibuat. Tahap Observation pada model POEW identik dengan fase Exploration pada pendekatan konstruktivistik.

\section{c. Explanation}

Tahap Explanation atau menjelaskan yaitu peserta didik memberikan penjelasan terhadap hasil eksperimen yang telah dilakukan. Penjelasan dari peserta didik dilakukan melalui diskusi dengan anggota kelompok kemudian tiap kelompok mempresentasikan hasil diskusinya di depan kelas. Jika prediksi yang di buat peserta didik ternyata terjadi di dalam eksperimen, maka guru membimbing peserta didik merangkum dan memberi penjelasan untuk menguatkan hasil eksperimen yang dilakukan. Namun jika prediksi peserta didik tidak terjadi dalam eksperimen, maka guru membantu peserta didik mencari penjelasan mengapa prediksi atau dugaannya tidak benar. Tahap explanation identik dengan fase explanation pada pendekatan konstuktivistik.

\section{d. Elaboration}

Tahap elaboration yaitu peserta didik membuat contoh atau menerapkan konsep dalam kehidupan sehari-hari. Tahap elaboration di ambil dari pendekatan konstruktivistik. Tahap ini guru mendorong peserta didik untuk menerapkan konsep baru dalam situasi baru sehingga peserta didik lebih memahami konsep yang di ajarkan guru. Tahap ini pengembangan dari 
pendekatan konstruktivistik.

\section{e. Write}

Tahap write atau menulis yaitu melakukan komunikasi secara tertulis, merefleksikan pengetahuan dan gagasan yang dimiliki peserta didik Menurut Masingilia dan Wisniowska (1996) dalam (Yamin \& Ansari, 2012) menulis dapat membantu peserta didik untuk mengekspresikan pengetahuan dan gagasan mereka. peserta didik menuliskan hasil diskusi dan menjawab pertanyaan yang ada pada LKS. Selain itu pada tahap write ini, peserta didik membuat kesimpulan dan laporan dari hasil eksperimen. Tahap ini merupakan pengembangan dari model TTW.

\section{f. Evaluation}

Tahap Evaluation yaitu evaluasi terhadap pengetahuan, keterampilan dan perubahan proses berpikir peserta didik. Pada tahap ini peserta didik di evaluasi tentang materi elastisitas bahan berupa lisan maupun tulisan. Tahap ini merupakan pengembangan dari pendekatan konstruktivistik.

Implementasi model POE2WE dalam LKS materi elastisitas bahan melaui Microsft Teams dapat menhasilkan interaksi bagi pendidik maupun bagi peserta didik. Dengan bantuan Microsoft Teams pendidik dapat melakukan proses pembelajaran dengan menerapkan model POE2WE secara online tidak hanya terbatas di ruang kelas saja. dan peserta didik juga dapat berinteraksi baik dengan pendidik maupun dengan peserta didik lainnya.

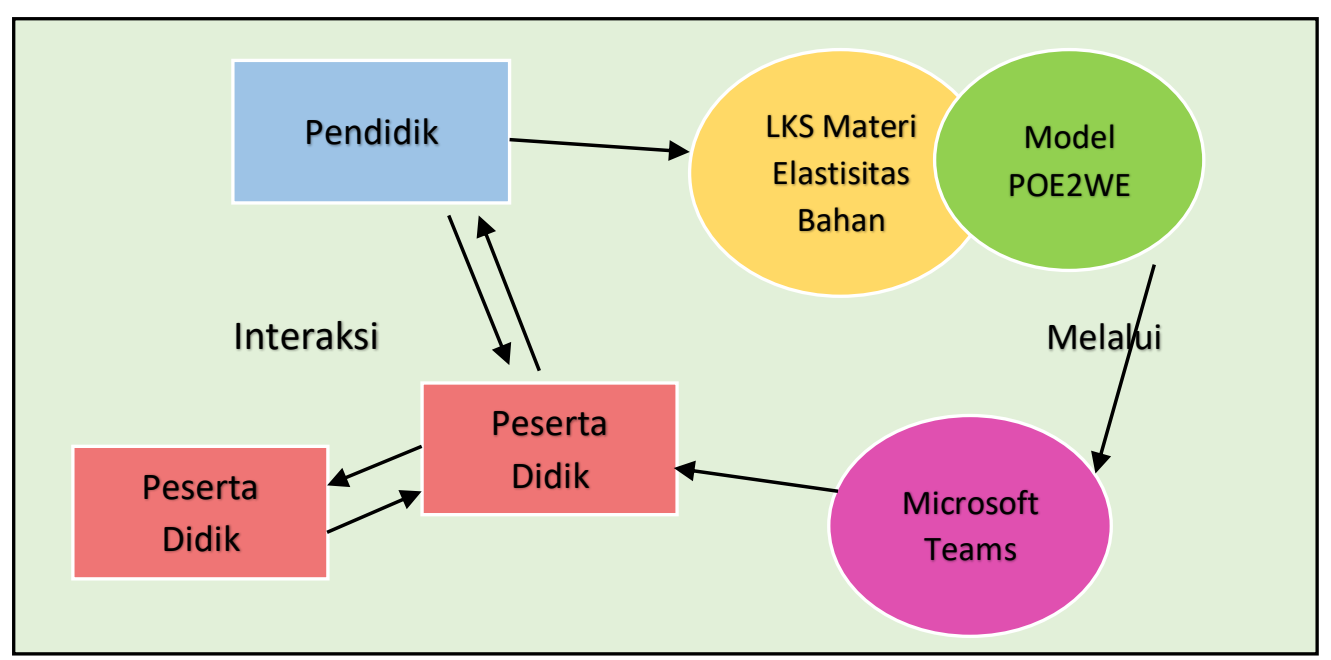

Gambar 1. Alur Implementasi Model POE2WE dalam LKS Materi Elastisitas Bahan dengan Menggunakan Microsoft Teams

\section{Kesimpulan}

Berdasarkan hasil penelitian di atas, maka dapat disimpulkan bahwa dengan mengimplementasikan model POE2WE dalam LKS materi elastisitas bahan dengan menggunakan Microsoft Teams sebagai bentuk pemanfaatan teknologi digital dapat 
meningkatkan interaksi antara pendidik dengan peserta didik mapun antara peserta didik dengan pendidik sehingga dapat meningkatkan proses pembelajaran fisika.

\section{Ucapan Terima Kasih}

Penulis mengucapkan terima kasih kepada Dr. Nana, M.Pd selaku dosen Jurusan Pendidikan

Fisika Universitas Siliwangi yang telah membimbing dalam pembuatan jurnal ini.

\section{Referensi}

Arianti, Dwi. (2015). Pengembangan Lembar Kerja Siswa T.P 2015/2016, skripsi, FKIP: UMP.

H., Wahyuni Nurul, dkk. (2019). Pengembangan Modul Pembelajaran Fisika Berbasi Kelautan di Balai Pendidikan dan Pelatihan Ilmu Pelayaran Barombong Makassar. [Skripsi]. Makassar (ID): Universitas Negeri Makassar. [Online]. Tersedia: http://eprints.unm.ac.id/id/eprint/12872 [09 Februari 2020].

Nana, Sajidan, Akhyar, M., \& Rochsatiningsih, D. (2014). The development of Predict, Observe, Explain, Elaborate, Write, and Evaluate (POE2WE) Learning Model in Physics Learning at Senior Secondary School. Journal of Education and Practice, 5(19), 56-65.

Nana, Surahman E. (2019). Pengembangan Inovasi Pembelajaran Digital Menggunakan Model Blended POE2WE di Era Revolusi Industri 4.0. Prosiding SNFA (Seminar Nasional dan Aplikasinya), 82-90.

Nana. (2014). Pengembangan model POE2WE dalam pembelajaran Fisika SMA. Universitas Sebelas Maret.

Nana. (2018). Penerapan Model Creative Problem Solving Berbasis Blog sebagai Inovasi Pembelajaran di Sekolah Menengah Atas dalam Pembelajaran Fisika. Prosiding SNFA (Seminar Nasional Fisika dan Aplikasinya). 190-195

Pane, Aprida., dkk. (2017). Belajar dan Pembelajaran.[Online]. Tersedia : http://jurnal.iainpadangsidimpuan.ac.id/index.php/F [09 Februari 2020].

Sirait Makmur, Dan Adilah Noer Putrid. (2013). Pengaruh Model Pembelajaran Kooperatif Tipe Make A Match Terhadap Hasil Belajar Peserta didik. Jurnal Program Studi Pendidikan Fisika FMIPA Unimed, Medan.

Sukoharjo, Fokus, Pedoman Guru Menuju Pembelajaran Tuntas, Jakarta: CV Sindunata, 2012

Yamin, M., \& Ansari, B. I. (2012). Taktik mengembangkan kemampuan individual siswa. Jakarta: Gaung Persada Press. 